\title{
Biography indexes reviewed
}

\section{Catherine Sassen}

Catherine Sassen discusses index characteristics considered significant by book reviewers of biographies, drawing on reviews excerpted in the 'Reviewed elsewhere' column of Biography.

\section{Introduction}

What can indexers learn from biography reviews? Do reviewers value indexes in biographies? Many reviewers quoted in the 'Indexes reviewed' column of The Indexer have voiced strong opinions about the need for indexes in biographies. For example, in a review of James Thomson 1700-1748: a life, Pat Rogers indicated, 'a well-organized index' is 'expected from a standard biography' (1992). Reviewers quoted in The Indexer also have made negative remarks about biographies without indexes. For example, Sheila Fitzpatrick (2007) stated that Mozart: the first biography is 'not much use to scholars' because of several deficiencies, including the lack of an index. In his review of Beckett remembering, remembering Beckett, Nicholas Lezard (2007) wrote 'There is no index, which is scandalous.'

In two high-profile cases, biographical works published without indexes drew a great deal of notice in the popular press. Journalists responded by creating their own indexes to these works. Indexes to The Andy Warhol diaries were published in Fame and Spy magazines in 1989 (Bream, 2004), and indexes for Going rogue by Sarah Palin were published in the Atlantic Wire, the Huffington Post, the New Republic, and Slate in 2009 (MacGlashan, 2010: 18-19).

\section{Literature review}

If reviewers value indexes, does it follow that their reviews will include evaluative comments about the quality of those indexes? Few researchers have investigated this issue. Lipetz (1989: 117) analyzed reviews of nonfiction books in the New York Times Book Review for ten months and found only three that mentioned indexing. Lavell (1990: 60) studied 66 book reviews from Archaeological Journal and found only eight mentions of indexing. McFadden (1993: 4-5) examined 206 reviews appearing in Choice in 1988 and 1989. He found that 57 reviews mentioned indexing, and 40 of those reviews included mostly brief evaluative remarks. Dartnell (2007: 186) analyzed 326 reviews in 11 scientific journals. She found that 54 reviews included comments on indexing, and only 34 of those comments were evaluative. Sassen (2010: 26-9) studied reference book reviews appearing in Booklist, Choice, Library Journal and RUSQ in 2009, and found that only 28.66 percent of the reviews included evaluative remarks about indexes. Limited research has focused on book reviewers' comments about indexes in a particular discipline. Wyman (1999: 124-6) analyzed comments about medical indexes, drawing on review excerpts that appeared in the 'Indexes reviewed' section of The Indexer.

\section{Methodology}

The goal of this study was to analyze reviewers' comments about indexes in biographies. To accomplish this purpose, book review excerpts appearing in the 'Reviewed elsewhere' column of Biography were examined. Biography (2011) is an interdisciplinary journal published by the University of Hawai'i Press. The 'Reviewed elsewhere' column began in 1987 and provides concise excerpts of reviews of biographies, autobiographies, memoirs, diaries, journals and correspondence originally published in other journals. The goal of the column is 'to skim what is being published in and around the field of biography' (Biography, 1987: 257). In this study, I accessed the 'Reviewed elsewhere' columns from issues 10(3) (summer 1987) through 34(3) (summer 2011) online through the Project Muse database, and examined them for comments about indexes.

\section{Limitations}

This content analysis is based on reviews excerpted in Biography during a limited time. It does not constitute an exhaustive study of biography reviews from all journals and newspapers.

\section{Reviews and their sources}

One hundred review excerpts were found to include comments about indexes. The journals and newspapers that originally published these reviews are listed in Table 1 (overleaf). The reviews appeared in a variety of publications issued in the United States, the United Kingdom, France, Germany, South Africa, Italy, Australia and Canada.

\section{Evaluative comments about indexes}

One hundred and six comments about indexes were found in the 100 review excerpts identified in the study. The number of comments was greater than the number of reviews because some reviews included more than one comment. Of these, 25 mentioned the presence of an index, 18 noted the absence of an index, and 63 were evaluative. A breakdown of the 63 evaluative comments is given in Table 2 and Figure 1. Eighteen of the evaluative comments were negative and 45 were positive.

Exhaustivity was mentioned 17 times, and was the characteristic most often discussed in remarks about index quality. Here are several examples. 
Table I Sources of book reviews

\section{Journal or newspaper}

African Book Publishing Record

American Scientist

Australian Book Review

Belles Lettres: A Review of Books by Women

Bulletin Critique du Livre Français

Bulletin of the School of Oriental and African Studies

City Press

Eighteenth-Century Studies

Etudes Anglaises

L'express

Feminist Review

French Review

French Studies

Globe and Mail

Hispania

Hispanic Journal

Historian

Journal of Asian Studies

Legacy

London Review of Books

Los Angeles Times Book Review

Le Monde des Livres

New York Review of Books

New York Times Book Review

New Yorker

Opera News

Rapport: Boeke

Review of English Studies

Revue d'histoire littéraire de la France

Romance Quarterly

Rural History

Screen

South African Journal of Cultural History

Studi Francesi

TLS, the Times Literary Supplement

Transformation

Tulsa Studies in Women's Literature

Vierteljahrschrift für Sozial- und Wirtschaftsgeschichte

Weekend Australian

Witness

Total

\section{Reviews}

Mere mention

3

2

I

I

4

I

\section{I}

I

3

I

I

10

7

2

I

I

I

I

I

4

2

8

5

12

2

I

I

I

3

I

I

I

I

4

3

I

I

2

4

2

Positive comments

Negative comments

3

(2nand

3

I

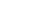

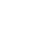

2

I

3

I

I

3

2

I

$$
\text { I }
$$

I

2 
Table 2 Evaluative comments about indexes

\begin{tabular}{llll} 
& Negative & Positive & Total \\
\hline Accuracy & 5 & & 5 \\
$\begin{array}{l}\text { Appropriate no. of } \\
\text { indexes included }\end{array}$ & $\mathrm{I}$ & & $\mathrm{I}$ \\
$\begin{array}{l}\text { Exhaustivity } \\
\text { Extensiveness }\end{array}$ & 4 & 13 & 17 \\
Legibility & 2 & 10 & 12 \\
Level of analysis & $\mathrm{I}$ & $\mathrm{I}$ & $\mathrm{I}$ \\
Usefulness & & & $\mathrm{I}$ \\
Value judgments & 5 & 11 & $1 \mathrm{I}$ \\
Totals & 18 & 45 & 15
\end{tabular}

Manchester University Press: Dennis Potter: a life on the screen, by John R. Cook (2nd ed., 1998, 378 pp.) Rev. by Philip Simpson, Screen 40(2), 1999. Excerpted in Biography 23(1), 2000.

Carpenter carefully attempts to authenticate biographical details through cross-references, citing all his sources and providing a distressingly detailed index for the less industrious student.

Princeton University Press: Garibaldi: citizen of the world, by Alfonso Scirocco, translated by Allan Cameron (2007, xii, 442 pp.) Rev. by Mark I. Choate, The Historian 72(2), 2010. Excerpted in Biography 33(3), 2010.

Readers will benefit from a chronology and annotated bibliography, but the index is spotty.

Livre de poche: Mémoires by Philippe De Commynes; introduction, edition, notes and index by Joel Blanchard, with the collaboration of Michel Quereil for the glossary. Rev. by Sarah Kay, French Studies 57(3), 2003. Excerpted in Biography 27(1), 2004.

Anyone wanting to locate a particular passage will be especially appreciative of Blanchard's index. Nearly two hundred pages in length, it provides detailed analytical coverage of all the mentions of persons, places and themes. The chapter index also provides a summary of the contents of each chapter. This is a volume in which a lifetime of erudition has been distilled into an outstandingly economical and user-friendly form.

Twelve comments concerned the extensiveness of indexes. For example:

Schirmer: The Mozart compendium: a guide to Mozart's life and music, edited by H. C. Robbins Landon (1990, 452 pp.) Rev. by Peggy Constantine, New York Times Book Review, 10 March 1991. Excerpted in Biography 14(3), 1991.

Mr. Landon and colleagues also provide portraits, a voluminous index, bibliography and a precise table of contents, valuable tools for newcomers and veterans of Mozartiana.
Figure I Evaluative comments about indexes

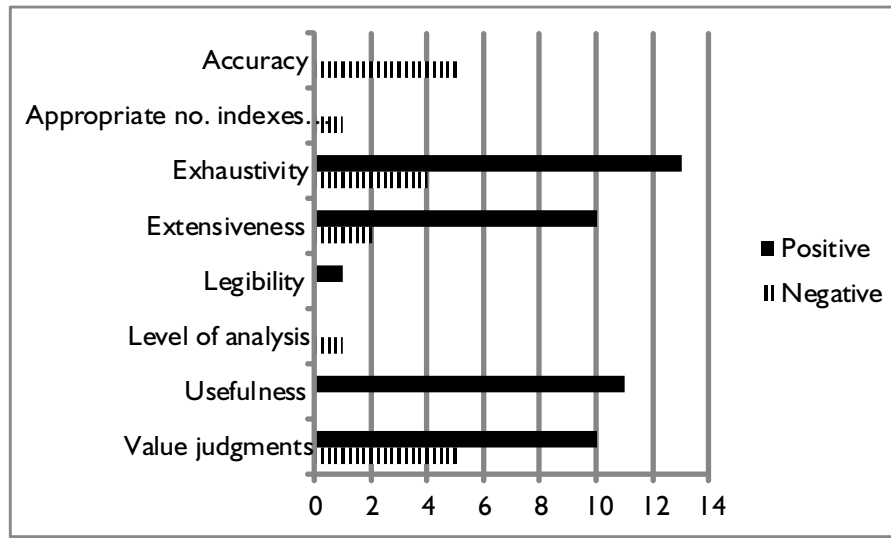

HarperCollins: The Reagan diaries, by Ronald Reagan, edited by Douglas Brinkley (2007, 767 pp.) Rev. by Edward N. Luttwak, Times Literary Supplement, 27 July 2007. Excerpted in Biography 30(4), 2007.

The index is unacceptably cursory and full of mistakes, so that Selwa 'Lucky' Roosevelt and Lucky Roosevelt both appear, while the one Kirkpatrick listing covers two of them.

Eleven comments dealt with the usefulness of indexes. For example:

Honoré Champion: Une somme stendhalienne: études et documents 1935-2000, by Victor Del Litto (2002, 2 vols.) Rev. by Annalisa Bottacin, Studi Francesi, May-Aug. 2003. Excerpted in Biography 27(2), 2004.

A very useful index of the names of persons and of works quoted is also given.

Fayard: Paul Valery, by Michel Jarrety (2009, 1,366 pp.) Rev. by Paul Gifford, TLS Mar. 13, 2010. Excerpted in Biography 33(3), 2010.

[T]his doorstopper of a book ... [is] richly illustrated and with scholarly notes for specialist readers, as well as a serviceable index.

Five comments were about the accuracy of indexes. For example:

Simon and Schuster: 109 East Palace: Robert Oppenheimer and the secret city of Los Alamos, by Jennet Conant (2005, 288 pp.) Rev. by Val L. Fitch, American Scientist 93(4), 2005. Excerpted in Biography 28(4), 2005.

The text of the book appears to be well copyedited, but the index has a reference to Einstein, Alfred. I wonder who he might be?

Odile Jacob: Fernand Braudel, by Giuliana Gemelli (1990, 376 pp.) Rev. by Emmanuel Le Roy Ladurie, L'express, Sept. 28, 1995. Excerpted in Biography 19(2) 1996.

Gemelli has produced what would in France be called 
an excellent doctoral dissertation whose macaronic style Braudel would greatly have enjoyed. But be careful, dear Ms. Gemelli, your index confuses more than forty times Lucien Febvre and Henri Lefebvre, the Marxist philosopher, who has nothing to do with this topic. Forty errors in a row are quite a bit, one could even say it looks disorderly.

In one case, the reviewer indicated that an additional index was needed.

Gallimard: Correspondance, II, 1929-1932, by Rene Daumal, ed. by H. J. Maxwell (1993, 331 pp.) Rev. by Danielle Raquidel, French Review 69(6), 1996. Excerpted in Biography 20(1), 1997.

The letters are organized in chronological order and the volume contains some unpublished letters and an onomastic index, although it lacks a table of contents and a subject index.

One remark was about the level of analysis, specifically the lack of subheadings:

Univ. of Iowa Press: Salem is my dwelling place: a life of Nathaniel Hawthorne, by Richard Haviland Miller (1992, 596 pp.) Rev. by John Updike, New Yorker, 28 Sept 1992. Excerpted in Biography 16(2), 1993.

Preoccupied with phantoms of the psyche, Miller's biography is ghostly; even his index, blocks of page numbers unbroken into subtopics, is ghostly, along with his notes, many of them a bleak cipher ('C. 15:388, 310') the Centenary edition of Hawthorne, which this reader, for one, sadly lacked. Perhaps a ghostly author warrants a ghostly treatment.

One comment concerned the legibility of the index.

Gingko: Albert Camus: a biography by Herbert R. Lottman (1997, 805 pp.). Rev. by Ulrike Inge Stroszeck, The French Review 71(4), 1998. Excerpted in Biography 21(4), 1998.

The new edition, however, contains little more than cosmetic alterations - such as an update of the illustrated pages, a new foreword, a more legible index, and a translation of the excerpts used as an exergue - of which none address the problems of the earlier version.

In 15 cases, value judgments were made about the indexes. Here are two examples.

Scribe: Pompey Elliott, by Ross McMullin (2002, 732 pp.) Rev. by Peter Ryan, Weekend Australian, 1-2 June 2002. Excerpted in Biography 25(4), 2002.

There are blemishes in McMullin's huge book: the focus on Pompey blurs while we learn, for example, a great deal that Les Carlyon's superb Gallipoli expresses better; a sympathetic editor should have done more invisible mending on patches of the author's awkward style; the index is outstandingly bad.
Viking-Penguin: The House of Rothschild, by Niall Ferguson (1999, 2 vols.) Rev. by Frederic Morton, Los Angeles Times Book Review, 21 Nov. 1999. Excerpted in Biography 23(2), 2000.

Its most precious feature is its index.

Eighteen comments concerned the lack of an index. For example:

Pentland: Portrait of Delacroix, by Elspeth Davies (1994, 194 pp.) Rev. by Peter Collier, French Studies, 50(1), Jan. 1996. Excerpted in Biography 20(1), 1997.

Elspeth Davies's book is, superficially speaking, a disaster. There are no footnotes, no index, no bibliography, no attributions of sources and quotations. ...

Atlantic Monthly Press: The great divorce: a nineteenthcentury mother's extraordinary fight against her husband, the Shakers, and her times, by Ilyon Woo (2010, 404 pp.) Rev. by Mary Beth Norton, New York Times Book Review, 19 Sept. 2010. Excerpted in Biography 33(4), 2010.

Although Woo first encountered the Chapmans while researching her Columbia doctoral dissertation, 'The Great Divorce' is inadequately annotated for a work of history. The sketchy endnotes are difficult to relate to the book's text, and sometimes fail to indicate clearly the page of the document to which they refer. What's more, Woo provides neither index nor formal bibliography. To anyone hoping to track her sources, she says, in effect: trust me. That will do for some readers, but surely not for all.

\section{Discussion}

What do reviewers look for in biography indexes? According to the comments found in this study, reviewers notice exhaustivity, extensiveness, usefulness, accuracy, legibility, and level of analysis. They also make judgments as to whether the biography contains the appropriate number of indexes.

The index characteristics mentioned most often by reviewers in this study were exhaustivity, extensiveness, and usefulness. Are these aspects related? Reviewers described exhaustivity with terms such as 'comprehensive,' 'complete,' and 'thorough.' They described extensiveness with words such as 'substantial' and 'voluminous,' or by referring to the length of the index in terms of page numbers. If a reviewer praised an index for being extensive, it seems possible that the index was appreciated not only for its length, but also for its exhaustive content. It also could be argued that exhaustivity contributes to usefulness, since an exhaustive index is likely to serve the needs of the user.

Exhaustivity was defined by Anderson (1997: 12) as 'the detail with which topics or features of a documentary unit are analyzed or described.' Exhaustivity is a particular concern in biography indexes because of the ways in which they are used. There are at least two types of readers who may consult biography indexes, according to Wellisch (1995: 59):

The readers of a biography, having followed the person's 
life from birth to death or at least through a significant period, may in fact not need an index overly much because, after having finished the book, they now know what happened to its protagonist and will not refer to it any more. But those who have not read the biography, yet are seeking information on a person and on certain events in his or her life, expect to find it by means of a detailed index-and this is exactly how a reference work and its index are used.

Weinberg $(1999,10)$ mentioned a variation on this second type of user, namely the 'not-so-famous acquaintances of the biographee looking themselves up to see whether they are mentioned.' The book reviewer is another variation on the index user who may prefer to consult the index in order to avoid reading some of the pages in the text. Whittemore (1999) wrote:

There have been few biographies in the past half-century that have come to fewer than 600 pages, a figure that, all by itself, must mean something. For an ordinary newspaper reviewer, for instance, it means that a biography should have a good index to help him skip perhaps half a thousand pages.

What do the experts tell us about the exhaustive indexing of biographies? One aspect concerns the treatment of minor characters. Bell (2004: 30) argued in favor of indexing 'minor references to characters, or those making a single appearance in a book.' White (2005: 32) also discussed the issue of 'minor figures' in a biography and noted, 'it's easier to justify including rather than excluding an item in an index.' Davis (2009: 6) wrote, 'It is a very subjective decision, but the rule of thumb is really to determine whether each entry adds value to the index in order to be included. Again, indexers are hired for their analytical skills, not to simply pick up every detail in the text.'

Another aspect of exhaustivity involves deciding how much of the biography should be indexed. Bell (2004: 28) stated, 'Extraneous matter such as prologue, acknowledgements, illustrations, bibliography and appendices may well qualify for inclusion to the indexes to biographies.' She indicated that she would 'take a specific decision as to what to include for each book rather than advocating a general rule.' Each biography is different, and requires the indexer to determine the approach that would be most useful for its audience. As Bell $(2004,26)$ noted, 'Analysing and documenting human life and relationships at several levels is, assuredly, a complex business.'

Virginia Woolf (1932: 237) wrote, 'As everybody knows, the fascination of reading biographies is irresistible.' An index that provides exhaustive, accurate and useful access to information certainly will contribute to the pleasure of biography reading.

\section{Bibliography}

Anderson, James D. (1997) Guidelines for indexes and related information retrieval devices: A technical report. NISO technical report, 2. Bethesda, Md.: NISO Press.
Bell, Hazel K. (2004) Indexing biographies and other stories of human lives, 3rd edn. Society of Indexers occasional papers on indexing, no. 1. Sheffield: Society of Indexers.

Biography (2011) Available at: www.uhpress.hawai i.edu/tbiography.aspx (accessed 5 July 2012).

Biography (1987) 'Reviewed elsewhere' [online] 10(3), 257 Available at: www. uhpress . hawai i . edu/t-biography .aspx (accessed 5 July 2012).

Bream, A. (2004) 'The index embraces its silly side.' Boston Globe, 21 October, D1.

Dartnell, J. (2007) 'Scientific book reviews: how much do indexes matter?' The Indexer 25(3), 186.

Davis, M. (2009) 'Indexing biographies.' ANZSI Newsletter 5(8), 6-7.

Fitzpatrick, S. (2007). 'Review of Mozart: the first biography, by Franz Niemetschek, tr. by Helen Mautner.' London Review of Books, 5 July, 34.

Lavell, C. (1990) 'Indexes, mentions of, by reviewers', letter. The Indexer 17(1), 60.

Lezard, N. (2007) Review of Beckett remembering, remembering Beckett, ed. James and Elizabeth Knowlson. Guardian, 17 March, 18.

Lipetz, B.-A. (1989) 'The usefulness of indexes', in Indexing: The state of our knowledge and the state of our ignorance, ed. B. H. Weinberg. Medford, N.J.: Learned Information.

MacGlashan, M. (2010) 'Wot, no index? - or the death of the Washington read.' The Indexer 28(1), 18-23.

McFadden, T. (1993) 'Book reviewers and indexes.' Key Words 1(8), 4-5.

Rogers, P. (1992). Review of James Thomson 1700-1748: a life, by James Sambrook. Times Literary Supplement, 28 Feb., 13

Sassen, C. (2010) 'Reference book indexes reviewed.' The Indexer 28(1), 26-9.

Weinberg, B. H. (1999) 'Exhaustivity of indexes: Books, journals and electronic full text: summary of a workshop presented at the 1999 ASI Annual Conference.' Key Words 7(5), 1, 6-19.

Wellisch, H. H. (1995) Indexing from $A$ to $Z, 2$ nd edn. New York: H.W. Wilson.

White, M. L. (2005) 'Indexing lives', in Index it right: Advice from the experts, vol. 1, ed. E. L. Zafran. Medford, NJ.: Information Today.

Whittemore, R. (1999) 'The bio biz.' Wall Street Journal, 1 Oct., W.17.

Woolf, V. (1932) 'I am Christina Rossetti', in The common reader: second series. London: Hogarth Press.

Wyman, P. (1999) 'Medical indexes reviewed.' The Indexer 21(3), 124-6.

Catherine Sassen is principal catalog librarian at the University of North Texas. Email: Catherine. Sassendunt.edu

\section{Someone missing?}

Salinger, Claire ... .

Salinger, Doris ...

Salinger, Margaret Ann . . .

Salinger, Matthew ...

Salinger, Mrs. . . .

Salinger, Pierre . . .

Salinger, Solomon S. . . .

From the index to Ian Hamilton, In search of $J . D$. Salinger, London: Heinemann, 1988. 